\title{
Amylose-Based Cationic Star Polymers for siRNA Delivery
}

\author{
Tomoki Nishimura, ${ }^{1,2}$ Kaori Umezaki, ${ }^{1,2}$ Sada-atsu Mukai, ${ }^{1,2}$ \\ Shin-ichi Sawada, ${ }^{1,2}$ and Kazunari Akiyoshi ${ }^{1,2}$ \\ ${ }^{1}$ Department of Polymer Chemistry, Graduate School of Engineering, Kyoto University, Katsura, Nishikyo, Kyoto 615-8150, Japan \\ ${ }^{2}$ ERATO Akiyoshi Bio-Nanotransporter Project, JST, Katsura, Nishikyo, Kyoto 615-8150, Japan \\ Correspondence should be addressed to Kazunari Akiyoshi; akiyoshi@bio.polym.kyoto-u.ac.jp
}

Received 11 May 2015; Revised 5 August 2015; Accepted 11 August 2015

Academic Editor: Seung-Wuk Lee

Copyright (C) 2015 Tomoki Nishimura et al. This is an open access article distributed under the Creative Commons Attribution License, which permits unrestricted use, distribution, and reproduction in any medium, provided the original work is properly cited.

A new siRNA delivery system using a cationic glyco-star polymer is described. Spermine-modified 8-arm amylose star polymer (with a degree of polymerization of approximately 60 per arm) was synthesized by chemoenzymatic methods. The cationic star polymer effectively bound to siRNA and formed spherical complexes with an average hydrodynamic diameter of $230 \mathrm{~nm}$. The cationic 8-arm star polymer complexes showed superior cellular uptake characteristics and higher gene silencing effects than a cationic 1-arm polymer. These results suggest that amylose-based star polymers are a promising nanoplatform for glycobiomaterials.

\section{Introduction}

Since the discovery of RNA interference (RNAi) [1] and the achievement of gene silencing by synthetic small interfering RNAs (siRNAs) [2], siRNA has become established as a new tool for silencing target genes. siRNAs have, therefore, been widely recognized as novel potential therapeutics. To date, there has been considerable effort to develop siRNA therapeutics for treating viral infections and cancers [3]. For siRNA therapeutic applications, appropriate gene carriers are required because naked siRNA is readily degraded by nucleases. Moreover, siRNAs are too large and hydrophilic to cross cell membranes without a delivery method $[4,5]$. To successfully deliver siRNAs, the carriers must penetrate biological barriers. Therefore, the development of gene carriers to efficiently deliver siRNAs remains an important challenge.

Various types of carriers for nucleic acids and other macromolecules have been developed, including viruses, nanoparticles, lipids, and polymers [6-9]. Though viral carriers are undeniably the most efficient for gene delivery, their use is encumbered by potential safety issues such as pathogenicity and immunogenicity. This has prompted development of nonviral carriers using biocompatible materials.
Among the most commonly used polymer building blocks for these carriers are poly(ethylene glycol) [10, 11], poly(peptoid)s [12-14], and poly(amino acid)s [15].

Among materials under development for use as gene carriers, polysaccharides are one of the most promising because of low toxicity, biocompatibility, and biodegradability. Examples include amylopectin [16], chitosan [17], dextran [18], cellulose [19], pullulan [20], and schizophyllan [21]. We have described several series of spermine-modified cycloamylose derivatives that effectively delivered pDNA, siRNA, and CpG DNA in vitro and in vivo [22-24].

Amylose, a linear $\alpha(1,4)$ glucan with low polydispersity, can be enzymatically synthesized. We previously reported that a series of amylose-based star polymers can be prepared chemoenzymatically [25]. Spermine-modified 8-armed amylose star polymer, through its multivalent interactions with DNA, effectively catalyzed DNA strand exchange reactions. This multivalent character is also an important feature for a siRNA carrier. siRNA has a lower molecular weight than pDNA and strong interactions between the carrier and the siRNA would be required to form stable and compact complex nanoparticles. We therefore decided to take advantage of these properties and investigate amylose-based star polymers as potential siRNA carriers. 
In this study, we report that a spermine-modified amylose-based star polymer acts as a siRNA carrier. siRNApolymer complexes were characterized with respect to their sizes and charge ratios. In addition, their cytotoxicity and cellular uptake were evaluated by WST- 8 assay and confocal laser-scanning microscopy (CLSM), respectively. Finally, delivery of a vascular endothelial growth factor specific siRNA (denoted by siVEGF) was evaluated at the mRNA level. For comparison, a monoarm glycopolymer with the same degrees of polymerization (D.P.) as the amylose arm of the star polymers was also characterized and evaluated for siRNA transfection efficiency.

\section{Materials and Methods}

2.1. Synthesis of Cationic Glyco-Star Polymers. Glycopolymers with a degree of polymerization of about 60 per arm were synthesized as described previously [25]. Sperminemodified glycopolymers were prepared by a conventional $1,1^{\prime}$ carbonyldiimidazole method. Briefly, carbonyldiimidazole $(0.025 \mathrm{~g})$ in DMSO $(15 \mathrm{~mL})$ was added dropwise to a solution of 8 -arm glycopolymer (C8A, $0.10 \mathrm{~g}$ ) in $10 \mathrm{~mL}$ dry DMSO at room temperature under argon and the reaction mixture was stirred for $5 \mathrm{~h}$ at room temperature. Spermine $(0.32 \mathrm{~g})$ in DMSO $(10 \mathrm{~mL})$ was then added to the reaction mixture and the mixture was stirred for $18 \mathrm{~h}$ at room temperature. The reaction solution was dialyzed against distilled water in a dialysis membrane (1000 MWCO) for 3 days and lyophilized to yield the solid products. One-arm cationic glycopolymer (C1A) was synthesized in an analogous manner.

2.2. siRNA and siRNA/Cationic Polymer Complexes. The siRNA species used were siRNA targeting murine VEGF ( $5^{\prime}$-CAG CUU GAG UUA AAC GAA CGU ACU U- $3^{\prime}$, $5^{\prime}$-AAG UAC GUU CGU UUA ACU CAA GCU G-3'), denoted by siVEGF; nonsense siRNA (MISSION siRNA Universal Negative Control, Sigma-Aldrich, St. Louis, MO, USA), denoted by siCont; and Alexa488-labeled negative control siRNA (Invitrogen, Thermo Fisher Scientific, Grand Island, NY, USA).

To form siRNA/cationic polymer complexes, each siRNA $(0.30 \mathrm{nM})$ and each cationic polymer $(0.13 \mathrm{nM})$ was mixed gently and incubated for $30 \mathrm{~min}$ at room temperature.

2.3. Size and Zeta Potentials. Dynamic light scattering (DLS) and zeta potential $(\zeta)$ measurements were performed using a Malvern Zetasizer nano ZPS (Malvern Instruments Inc., USA) and data analyzed using Malvern software.

2.4. Transmittance Electron Microscopy (TEM). Morphology of siRNA/cationic polymers complexes was observed with a TEM (HT-7700, Hitachi, Japan) at an acceleration voltage of $100 \mathrm{kV}$ and a beam current of $20 \mu \mathrm{A}$. Complexes were stained prior to TEM with $1 \mathrm{wt} \%$ phosphotungstic acid.

2.5. Confocal Laser-Scanning Microscopy (CSLM). Renca cells were cultured in glass bottom culture dishes at a density of 1 $\times 10^{5}$ cells per dish at $37^{\circ} \mathrm{C}$ in $5 \% \mathrm{CO}_{2} / 95 \%$ humidified air.
After $24 \mathrm{~h}$ incubation, Alexa488-labeled siRNA/cationic polymer complexes were added. After $24 \mathrm{~h}$, cells were observed with LSM 780 confocal fluorescence microscope (Carl Zeiss, Jena, Germany).

2.6. Cytotoxicity Assay. Renca cells were seeded at a density of $1 \times 10^{4}$ cells/well on 96-well plates for $24 \mathrm{~h}$ in RPMI1640 medium supplemented with $100 \mathrm{U} / \mathrm{mL}$ penicillin, $100 \mu \mathrm{g} / \mathrm{mL}$ streptomycin, and 10\% FBS in advance. The culture media were replaced with fresh medium, and the polymers or siRNA/the polymer complexes were applied. After 24-hour incubation, the cell cytotoxicity was evaluated with Cell Counting Kit-8 (Dojin, Japan) according to the manufacturer's instructions. The absorbance was measured using a microplate reader with a filter of $450 \mathrm{~nm}$. The cell viability was determined as a percentage of the absorbance of nontreated cells. The results were expressed as mean and standard deviation obtained from three samples.

2.7. siRNA Transfection In Vitro and RNA Isolation. Renca cells, cultured in RPMI1640 medium supplemented with $100 \mathrm{U} / \mathrm{mL}$ penicillin, $100 \mu \mathrm{g} / \mathrm{mL}$ streptomycin, and $10 \% \mathrm{FBS}$, were seeded into 12 -well tissue culture plates $\left(1 \times 10^{5}\right.$ cells per well) at $37^{\circ} \mathrm{C}$ in $5 \% \mathrm{CO}_{2} / 95 \%$ humidified air. After $24 \mathrm{~h}$, siRNA/cationic polymer complexes, at concentrations as indicated in the figures, were added to the cells and incubation was continued under standard culture conditions. After 24 hours, total RNA was collected by RNeasy Micro Kit (Qiagen) according to the manufacturer's instructions.

2.8. Quantitative Real-Time PCR. For measurement of VEGF RNA expression, q-PCR was performed using LightCycler 480 Probe master (Roche). For the detection of VEGF mRNA, cDNA was synthesized from 500 ng of total RNA using the reverse reaction kit (ReverTra Ace qPCR RT Master Mix (Toyobo, Japan)) with the manufacturer's instruction. A LightCycler 480 Real-Time PCR System (Roche) was used for quantitative mRNA detection. The relative expression levels of mRNA were normalized to the expression of $18 \mathrm{~S}$ ribosomal RNA. The expression of the gene was quantified by measuring cycle threshold $(\mathrm{Ct})$ values and normalized using $2^{-\Delta \Delta \mathrm{Ct}} \mathrm{Ct}$ method relative to $18 \mathrm{~S}$ ribosomal RNA.

\section{Results and Discussion}

Glycopolymers were prepared by a chemoenzymatic method as reported previously [25]. Cationic spermine groups were introduced to the glycopolymers by a carbonyldiimidazolemediated amide coupling reaction between the primary alcohol groups of amylose and the amino groups of spermine. The degree of substitution was about 30 spermine residues per 100 glucose units of the polysaccharide. The spermine functionalized mono- and octa-armed glycopolymers are denoted by $\mathrm{C1A}$ and C8A, respectively (Figure 1).

Polymer solutions in phosphate buffered saline (PBS, $\mathrm{pH}$ 7.4) were characterized with DLS and zeta potential analysis. The hydrodynamic diameters of $\mathrm{C1A}$ and C8A in PBS were 

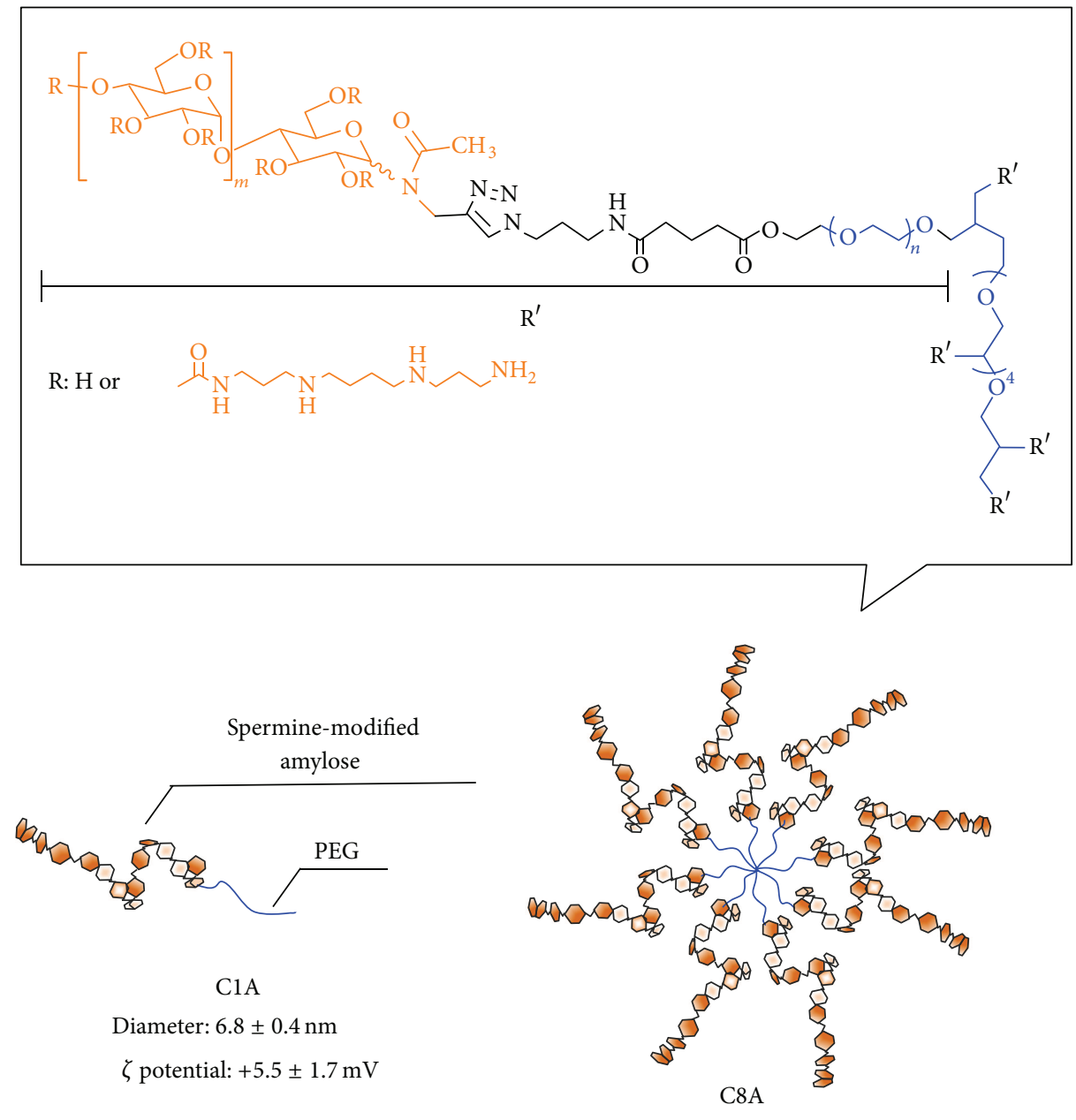

Diameter: $9.6 \pm 1.0 \mathrm{~nm}$

$\zeta$ potential: $+6.7 \pm 0.4 \mathrm{mV}$

FIGURE 1: Chemical structures and illustrations of spermine-modified glycopolymers.

7 and $10 \mathrm{~nm}$, respectively. The $\zeta$ potentials of $\mathrm{ClA}$ and $\mathrm{C} 8 \mathrm{~A}$ were $+6 \mathrm{mV}$ and $+7 \mathrm{mV}$, respectively.

siRNA/C1A and siRNA/C8A complexes were prepared as described in Materials and Methods by mixing siRNA in nuclease-free $\mathrm{H}_{2} \mathrm{O}$ with the appropriate volumes of $\mathrm{C} 1 \mathrm{~A}$ or $\mathrm{C} 8 \mathrm{~A}$ solution $(1.0 \mathrm{mg} / \mathrm{mL})$, such that $\mathrm{C} / \mathrm{P}$ ratios (ratio of cationic group in the glycopolymer to phosphate group in DNA) were 1.3. The size distributions and $\zeta$ potentials of the resulting complexes were determined (Figure 2 ). Both complexes showed a positive $\zeta$ potential $(5-12)$ at $\mathrm{C} / \mathrm{P}=1.3$. The siRNA/C8A complexes had an average hydrodynamic diameter of $234 \pm 0.8 \mathrm{~nm}$. In contrast, the siRNA/C1A complexes had an average hydrodynamic diameter of $575 \pm$ $48 \mathrm{~nm}$. By TEM observation, both complexes were spherical objects with size distributions comparable to what was found by DLS analysis. Compared with $\mathrm{C1A}$, C8A had highly localized positive charges. This characteristic enables C8A to bind strongly to RNA. In fact, the binding affinity of C8A to DNA (20 base pairs) is 44 times greater than that of $\mathrm{C1A}$ [25]. The higher affinity of C8A for nucleic acids is believed to explain its formation of smaller complexes, as compared with those formed with C1A.

Since in vitro cytotoxicity of gene carriers is considered an important factor of biocompatibility, we investigated that cytotoxicity of our polymers with concentrations varied from 0 to $50 \mu \mathrm{g} / \mathrm{mL}$ by WST- 8 assay. As shown in Figure 3, exposure of the cells to the cationic polymers led to a slight decrease in cell viability (greater than $80 \%$ ) for all polymer concentrations tested. Moreover, siRNA/cationic polymer complexes with various $\mathrm{C} / \mathrm{P}$ ratios also showed no significant toxicity.

Cellular uptake of siRNA and siRNA/cationic polymer complexes was then investigated in Renca cells with confocal laser-scanning fluorescence microscopy (CLSM). C1A and C8A solutions were mixed with Alexa488-labeled siRNA at a $\mathrm{C} / \mathrm{P}$ of 1.3 and incubated for $30 \mathrm{~min}$ at room temperature. The resulting solutions were added to Renca cells and incubated in culture medium, as described in Materials and Methods, for $24 \mathrm{~h}$. Cellular distributions of Alexa488-labeled siRNA, visualized by confocal laser-scanning microscopy (CLSM), 


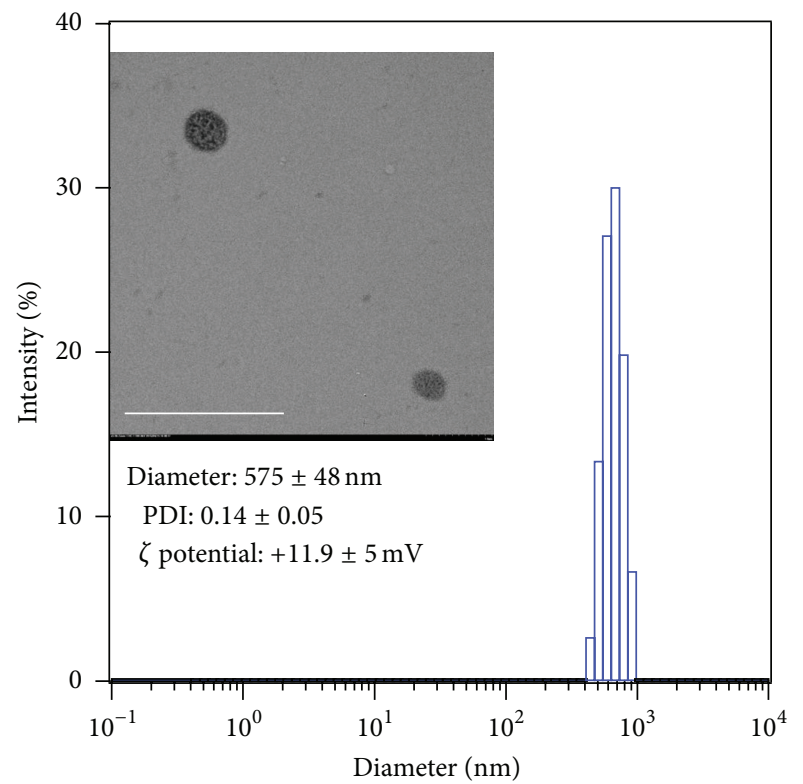

(a)

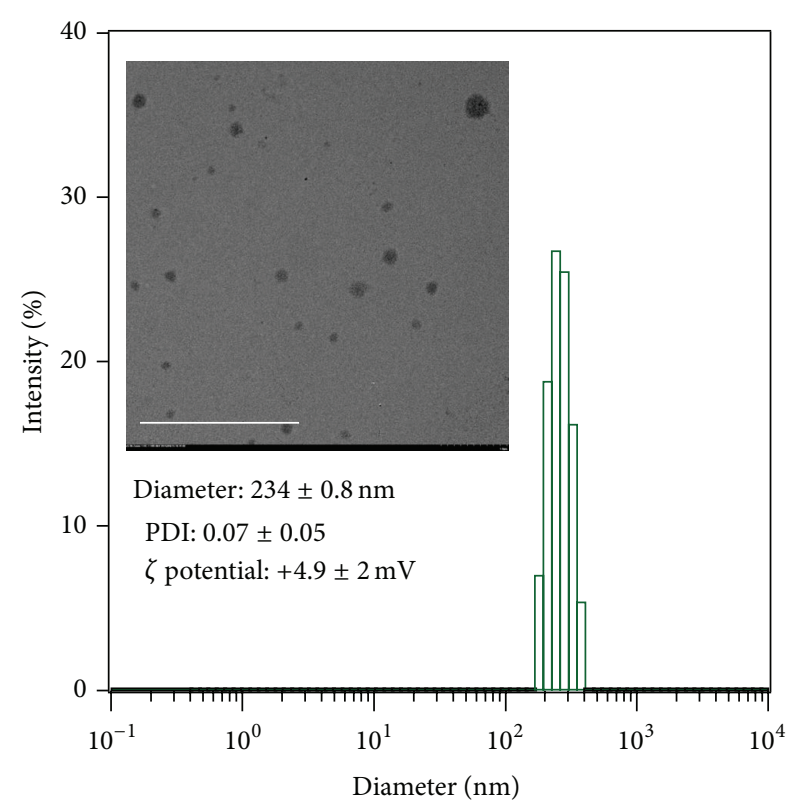

(b)

FIGURE 2: Size distributions of siRNA/C1A (a) and siRNA/C8A (b) complexes at C/P = 1.3 in PBS buffer. Inset: TEM images of the complexes. [polymer] $=0.098 \mu \mathrm{g} / \mu \mathrm{L} ;[\mathrm{siRNA}]=0.032 \mu \mathrm{g} / \mu \mathrm{L}$. The bars in the TEM images represent $1.0 \mu \mathrm{m}$.

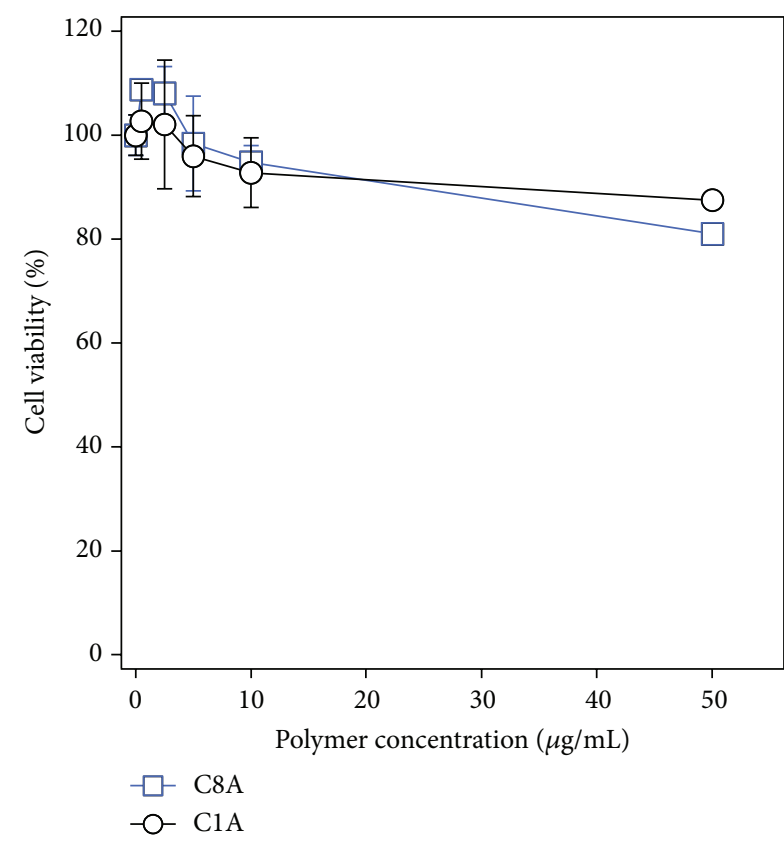

(a)

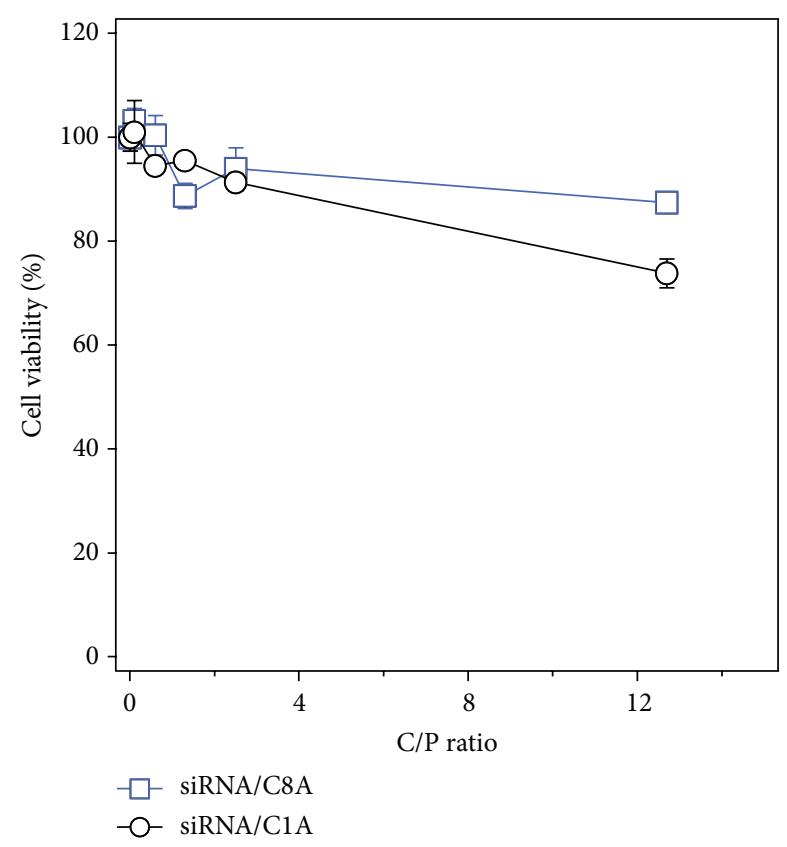

(b)

FIGURE 3: Cytotoxicity of the cationic polymers and siRNA/polymer complexes ([siRNA] $=0.1 \mathrm{nM})$. The complexes were incubated with Renca cells for 24 hours, and cell viability was evaluated by the WST- 8 assay.

are shown in Figure 4. Free siRNA was not internalized, remaining localized outside the cell. In contrast, green fluorescence was detected in the Renca cells using siRNA/cationic polymer complexes. Moreover, complexes formed with the C8A polymer resulted in greater cellular siRNA uptake than those with the C1A polymer.
Next, we investigated RNAi effectiveness of the C1Aand C8A-based delivery systems. VEGF mRNA levels were evaluated by real-time RT-PCR analysis. Renca cells were treated with siRNA/C1A, siRNA/C8A complexes $(\mathrm{C} / \mathrm{P}=$ 1.3 , $[$ siRNA $]=0.3 \mathrm{nM}$ ), and siRNA/lipofectamine 2000 as a positive control. As shown in Figure 5, VEGF mRNA 


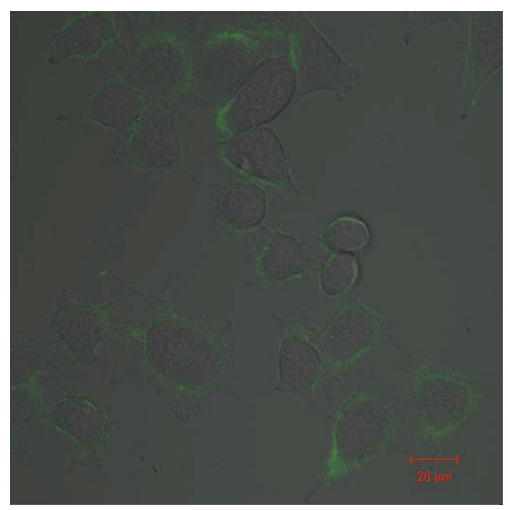

(a)

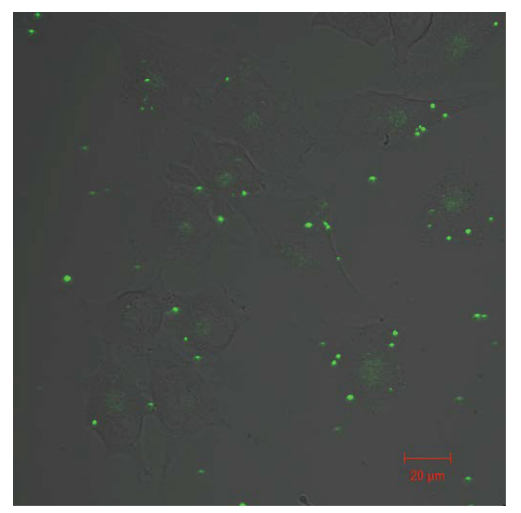

(b)

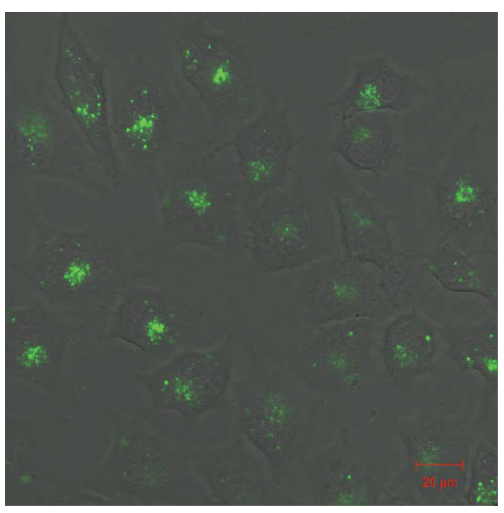

(c)

Figure 4: CLSM images of the glycopolymer delivery of Alexa488-labeled siRNA to Renca cells. (a) Naked siRNA, (b) siRNA/C1A complex, and $(\mathrm{c})$ siRNA/C8A complex. Both complexes $([\mathrm{ClA}]=0.34 \mathrm{nM} ;[\mathrm{C} 8 \mathrm{~A}]=0.042 \mathrm{nM} ;[\mathrm{siRNA}]=0.1 \mathrm{nM}, \mathrm{C} / \mathrm{P}=1.3)$ were incubated with cells for $24 \mathrm{~h}$. The bars represent $20 \mu \mathrm{m}$.

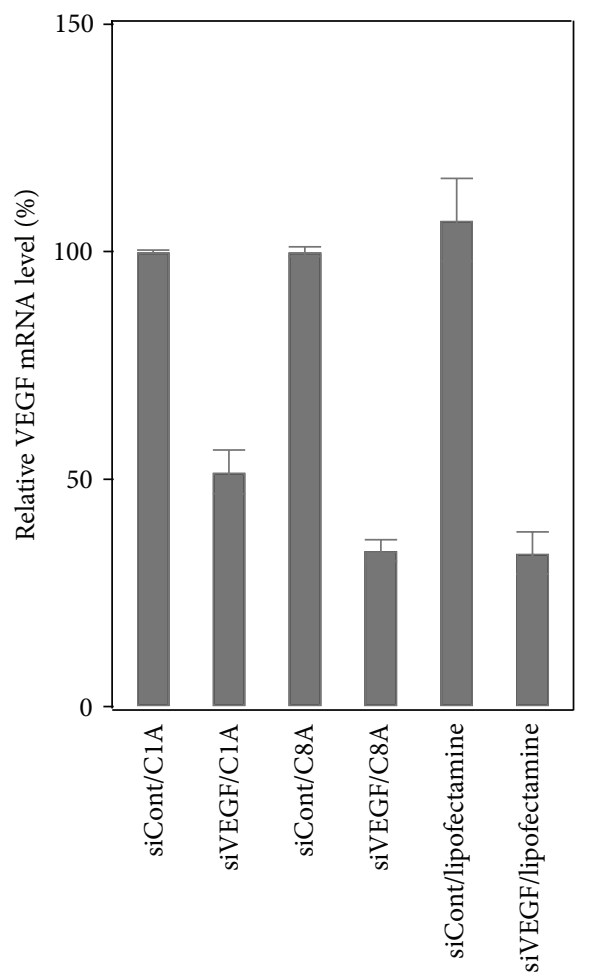

FIGURE 5: Gene silencing effect of nonsense siRNA (siCont)/C1A, sense siRNA (siVEGF)/C1A, siConc/C8A, siVEGF/C8A, SiCont/lipofectamine 2000, and siVEGF/lipofectamine 2000 complexes. [The polymer $]=5 \mu \mathrm{g}$; [lipofectamine 2000] $=2 \mu \mathrm{g}$. Dose of siRNA for the cationic polymers was $0.3 \mathrm{nM}$, while dose of siRNA for lipofectamine 2000 was $0.1 \mathrm{nM}$. C/P ratio was 1.3 for the siRNA/the cationic polymer complexes.

levels were decreased after incubation with siVEGF/C8A or siVEGF/C1A complexes, relative to those in cells incubated with the corresponding nonsense siRNA complexes. Therefore, it is clear that both C1A- and C8A-based systems deliver siRNA into cells, enabling silencing of the target gene.
The gene silencing effect of the C8A-based system (34\% of control mRNA levels) was higher than that of C1Abased system (52\% of control mRNA levels) and was almost comparable to that of lipofectamine 2000 system. Physical properties, including size, charge, and shape, of such complexes contribute greatly to cellular uptake efficiency [26, 27]. For the moment, the reason for the difference of the gene silencing efficiency is not clear. The relative sizes of the complexes might be attributed to this difference. The formation of smaller complexes between siRNA and the C8A polymer, as compared with the C1A polymer, might enhance cell internalization, leading to higher gene silencing efficiency.

\section{Conclusions}

In summary, we have demonstrated the utility of cationic glyco-star polymers as carriers for siRNA delivery. As compared with C1A, C8A can form more compact complexes with siRNA. The siRNA/C8A complexes were effectively internalized by cells and suppressed VEGF mRNA levels by about $65 \%$. Our results show that the cationic glyco-star polymer is a promising platform for siRNA delivery.

\section{Conflict of Interests}

The authors declare that there is no conflict of interests regarding the publication of this paper.

\section{Authors' Contribution}

The paper was written through contributions of all authors. Tomoki Nishimura and Kaori Umezaki contributed equally.

\section{Acknowledgment}

This work was supported by funding from the JST ERATO program. 


\section{References}

[1] A. Fire, S. Xu, M. K. Montgomery, S. A. Kostas, S. E. Driver, and C. C. Mello, "Potent and specific genetic interference by doublestranded RNA in Caenorhabditis elegans," Nature, vol. 391, no. 6669, pp. 806-811, 1998.

[2] S. M. Elbashir, J. Harborth, W. Lendeckel, A. Yalcin, K. Weber, and T. Tuschl, "Duplexes of 21-nucleotide RNAs mediate RNA interference in cultured mammalian cells," Nature, vol. 411, no. 6836, pp. 494-498, 2001.

[3] J. Kurreck, "RNA interference: from basic research to therapeutic applications," Angewandte Chemie International Edition, vol. 48, no. 8, pp. 1378-1398, 2009.

[4] R. Juliano, J. Bauman, H. Kang, and X. Ming, "Biological barriers to therapy with antisense and siRNA oligonucleotides," Molecular Pharmaceutics, vol. 6, no. 3, pp. 686-695, 2009.

[5] K. A. Whitehead, R. Langer, and D. G. Anderson, "Knocking down barriers: advances in siRNA delivery," Nature Reviews Drug Discovery, vol. 8, no. 2, pp. 129-138, 2009.

[6] S. J. Tan, P. Kiatwuthinon, Y. H. Roh, J. S. Kahn, and D. Luo, "Engineering nanocarriers for siRNA delivery," Small, vol. 7, no. 7, pp. 841-856, 2011.

[7] R. Kanasty, J. R. Dorkin, A. Vegas, and D. Anderson, "Delivery materials for siRNA therapeutics," Nature Materials, vol. 12, no. 11, pp. 967-977, 2013.

[8] A. Pathak, S. Patnaik, and K. C. Gupta, "Recent trends in nonviral vector-mediated gene delivery," Biotechnology Journal, vol. 4, no. 11, pp. 1559-1572, 2009.

[9] C. X. Li, A. Parker, E. Menocal, S. Xiang, L. Borodyansky, and J. H. Fruehauf, "Delivery of RNA interference," Cell Cycle, vol. 5, no. 18, pp. 2103-2109, 2006.

[10] M. Meyer, A. Philipp, R. Oskuee, C. Schmidt, and E. Wagner, "Breathing life into polycations: functionalization with $\mathrm{pH}$ responsive endosomolytic peptides and polyethylene glycol enables siRNA delivery," Journal of the American Chemical Society, vol. 130, no. 11, pp. 3272-3273, 2008.

[11] X.-B. Xiong, H. Uludağ, and A. Lavasanifar, "Biodegradable amphiphilic poly(ethylene oxide)-block-polyesters with grafted polyamines as supramolecular nanocarriers for efficient siRNA delivery," Biomaterials, vol. 30, no. 2, pp. 242-253, 2009.

[12] C. Hörtz, A. Birke, L. Kaps et al., "Cylindrical brush polymers with polysarcosine side chains: a novel biocompatible carrier for biomedical applications," Macromolecules, vol. 48, no. 7, pp. 2074-2086, 2015.

[13] N. Adams and U. S. Schubert, "Poly(2-oxazolines) in biological and biomedical application contexts," Advanced Drug Delivery Reviews, vol. 59, no. 15, pp. 1504-1520, 2007.

[14] R. Hoogenboom, "Poly(2-oxazoline)s: a polymer class with numerous potential applications," Angewandte Chemie International Edition, vol. 48, no. 43, pp. 7978-7994, 2009.

[15] Y. Inoue, R. Kurihara, A. Tsuchida et al., "Efficient delivery of siRNA using dendritic poly(l-lysine) for loss-of-function analysis," Journal of Controlled Release, vol. 126, no. 1, pp. 5966, 2008.

[16] Y. Zhou, B. Yang, X. Ren et al., "Hyperbranched cationic amylopectin derivatives for gene delivery," Biomaterials, vol. 33, no. 18, pp. 4731-4740, 2012.

[17] J. Deng, Y. Zhou, B. Xu, K. Mai, Y. Deng, and L.-M. Zhang, "Dendronized chitosan derivative as a biocompatible gene delivery carrier," Biomacromolecules, vol. 12, no. 3, pp. 642-649, 2011.
[18] K. Raemdonck, B. Naeye, K. Buyens et al., "Biodegradable dextran nanogels for RNA interference: focusing on endosomal escape and intracellular siRNA delivery," Advanced Functional Materials, vol. 19, no. 9, pp. 1406-1415, 2009.

[19] Y. Song, Y. Sun, X. Zhang, J. Zhou, and L. Zhang, "Homogeneous quaternization of cellulose in $\mathrm{NaOH} / \mathrm{Urea}$ aqueous solutions as gene carriers," Biomacromolecules, vol. 9, no. 8, pp. 2259-2264, 2008.

[20] J.-I. Jo, T. Ikai, A. Okazaki, M. Yamamoto, Y. Hirano, and Y. Tabata, "Expression profile of plasmid DNA by spermine derivatives of pullulan with different extents of spermine introduced," Journal of Controlled Release, vol. 118, no. 3, pp. 389-398, 2007.

[21] T. Nagasaki, M. Hojo, A. Uno et al., "Long-term expression with a cationic polymer derived from a natural polysaccharide: schizophyllan," Bioconjugate Chemistry, vol. 15, no. 2, pp. 249259, 2004.

[22] Y. Tahara, J. Yasuoka, S. Sawada, Y. Sasaki, and K. Akiyoshi, "Effective CpG DNA delivery using amphiphilic cycloamylose nanogels," Biomaterials Science, vol. 3, no. 2, pp. 256-264, 2015.

[23] H. Fujii, M. Shin-Ya, S. Takeda et al., "Cycloamylose-nanogel drug delivery system-mediated intratumor silencing of the vascular endothelial growth factor regulates neovascularization in tumor microenvironment," Cancer Science, vol. 105, no. 12, pp. 1616-1625, 2014.

[24] S. Toita, N. Morimoto, and K. Akiyoshi, "Functional cycloamylose as a polysaccharide-based biomaterial: application in a gene delivery system," Biomacromolecules, vol. 11, no. 2, pp. 397-401, 2010.

[25] T. Nishimura, S.-A. Mukai, S.-I. Sawada, and K. Akiyoshi, "Glyco star polymers as helical multivalent host and biofunctional nano-platform," ACS Macro Letters, vol. 4, no. 4, pp. 367371, 2015.

[26] F. Lu, S.-H. Wu, Y. Hung, and C.-Y. Mou, "Size effect on cell uptake in well-suspended, uniform mesoporous silica nanoparticles," Small, vol. 5, no. 12, pp. 1408-1413, 2009.

[27] S. E. A. Gratton, P. A. Ropp, P. D. Pohlhaus et al., "The effect of particle design on cellular internalization pathways," Proceedings of the National Academy of Sciences of the United States of America, vol. 105, no. 33, pp. 11613-11618, 2008. 

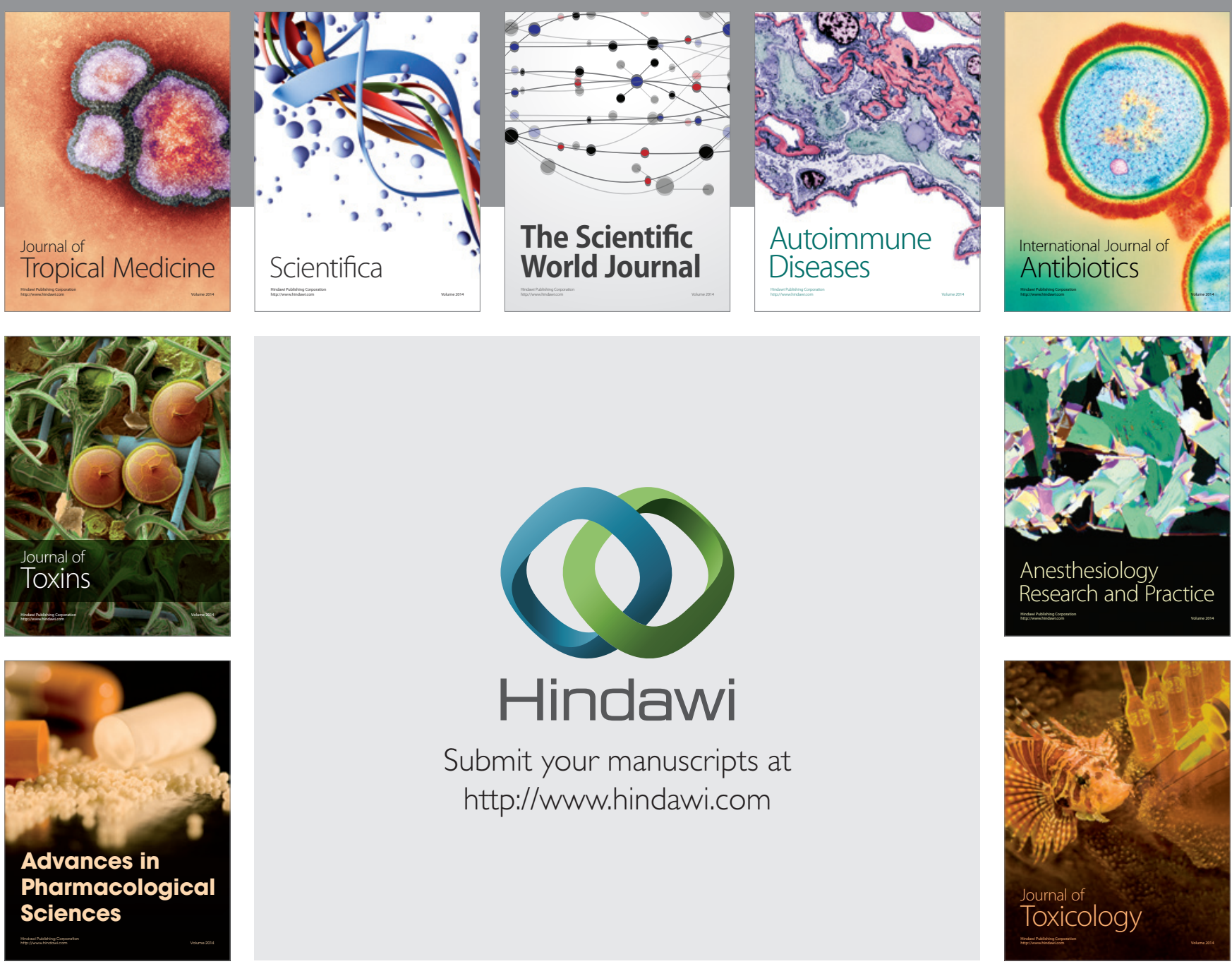

\section{Hindawi}

Submit your manuscripts at

http://www.hindawi.com
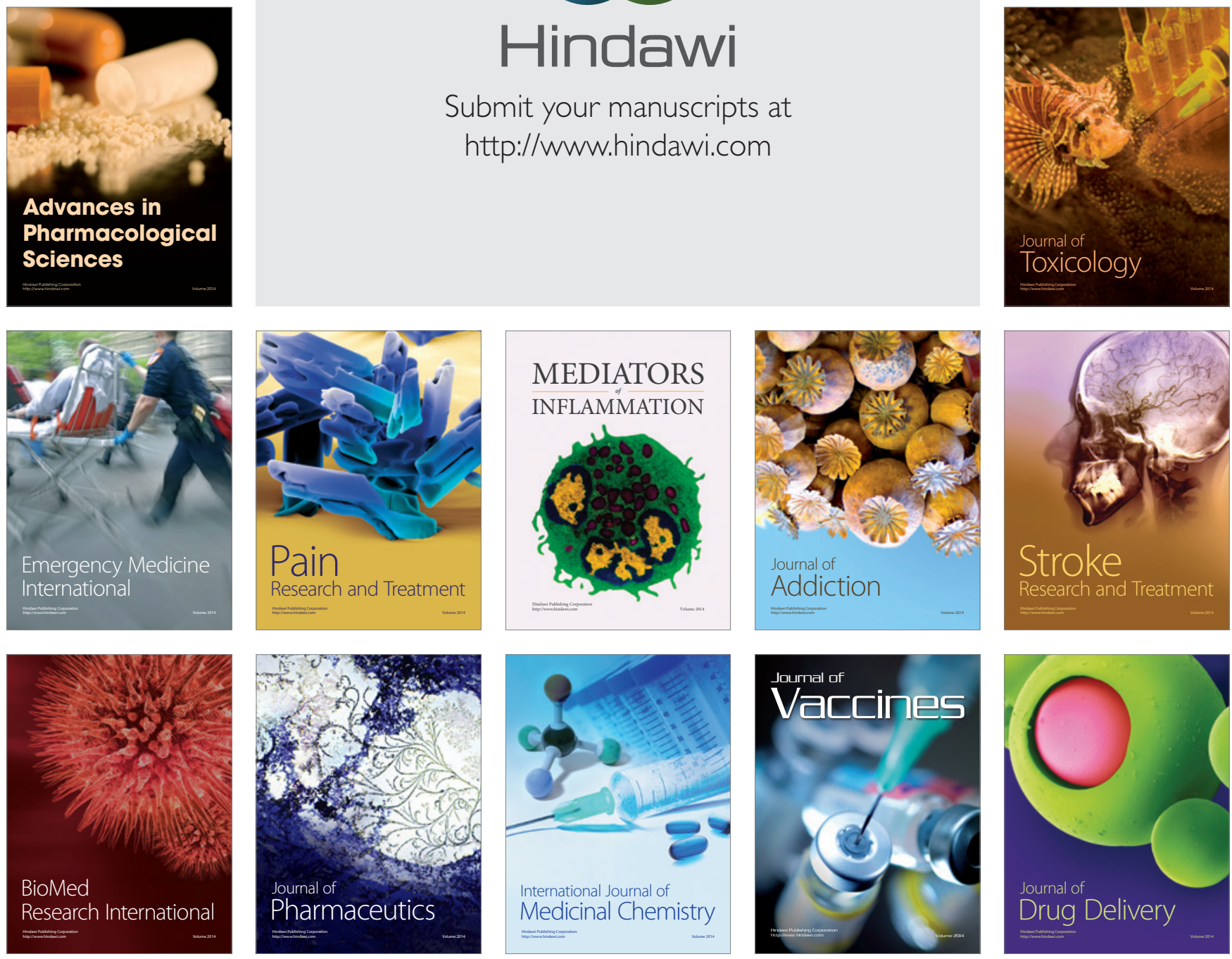